\title{
Accelerating Seed Potato Production By Using Rapid Multiplication Systems in Ethiopia
}

\author{
Lemma Tessema, Abebe Chindi, Gebremedhin Wgiorgis, \\ Atsede Solomon, Egata Shunka, Ebrahim Seid
}

Holeta Agricultural Research Center of EIAR, Ethiopia

*Corresponding Author: Lemma Tessema: lematessema@gmail.com

Citation: Lemma Tessema, Abebe Chindi, Gebremedhin Wgiorgis, Atsede Solomon, Egata Shunka, Ebrahim Seid (2018) Accelerating seed potato production by using rapid multiplication systems in Ethiopia Open Science Journal 3(1).

Received: $11^{\text {th }}$ November 2016

Accepted: $25^{\text {th }}$ August 2017

Published: $2^{\text {nd }}$ January 2018

Copyright:@ 2018 This is an open access article under the terms of the Creative Commons Attribution License, which permits unrestricted use, distribution, and reproduction in any medium, provided the original author and source are credited.

Funding: The author(s) received no specific funding for this work.

Competing Interests: The author have declared that no competing interests exists.

\section{Abstract}

Ethiopia is one of the major potato producing countries of the Sub-Saharan Africa region where potato is the fastest expanding food crop. The natural environment in Ethiopia is very suitable for year round production of potato using rain-fed and irrigated systems. However, the actual potato yield in the country ranges between 8-10 t/ha, which is slightly below the average for Africa. Shortage of good quality seed has been recognized as the single most important factor limiting potato production in the developing countries including Ethiopia. Therefore, the objective of this paper is to review the accelerating role of rapid seed potato multiplication technologies for potato seed production in Ethiopia. A low adoption of recommended seed potato technologies in the country could be due to a lack of alternative seed potato production methods compatible with farmers' economic and agro-ecological conditions. Since 2010, Holetta Agricultural Research Centre in collaboration with International Potato Center together are applying different seed potato production hastening schemes to produce early generation seed. These seed multiplication schemes include, tissue culture, aeroponics, sand hydroponics and other rapid multiplication methods in screen house pots. These seed potato multiplication schemes brought a dynamic change for the last five years by accelerating the supply efficiency by $7.6 \%$ with enhancing the number from 43,773 mini-tubers to 332,485 mini-tubers. Moreover, these new seed multiplication schemes enhanced the capacity of clean seed production of the country by producing 216,717 mini-tubers of high quality seed from aeroponics and sand hydroponics. The farmers could also access early generation clean seed potato through their nearby cooperatives with affordable price and with lowtransportation cost. Thus, for developing countries like Ethiopia where formal seed system is at infant stages and early generation seed is mostly produced by research institutions, the use of various rapid multiplication techniques could be one option to produce clean seed potato. 


\section{Keywords: Aeroponics, Sand hydroponics, Early generation seed, Rapid multiplication systems, Ethiopia}

\section{Introduction}

In terms of human consumption, potato is the third most important nongrain food crop in the world after rice and wheat (CIP, 2017). In Ethiopia, potato ranks first in the category of root and tuber crops (RTCs) in terms of area coverage and total production. Crop production survey results of private peasant holding of the year 2015/16 indicated that of the total land areas of about 496,1489 hectares covered by RTCs, 296, 578 hectare ( $60 \%$ ) and of over 7.21 million tons of RTCs produced over 3.66 million tons $(\sim 51 \%)$ was potato (CSA, 2016).

Despite these facts, potato yields of small-scale farmers in most developing countries including Ethiopia fall far below their potential due mostly to a potent combination of inadequate supplies of high-quality seed or lack of well-organized seed production and supply system( Ayalew, 2014).

According to Berga (2012); Gildemacher et al. (2009) Ethiopia, like other Eastern Africa combines both formal and informal seed systems. In the case of Formal Seed system, National Potato Programs produce the first three generations of formal seed (i.e. from nuclear to basic seed) under acceptable health control standards. While the informal seed system takes over after the third generation, with farmers and other multipliers typically using this basic seed to supply quality or improved informal seed for ware potato production. The combination of both formal and informal seed systems has improved the livelihoods of seed producers in the highlands of Ethiopia. These producers now typically have better houses, increased food security, more animals, more land and more children in school, and they have diversified their incomes away from potato (Chindi et al., 2017; Hirpa et al., 2015).

Seed tubers supplied by the informal seed potato system (supplies $98.7 \%$ of seed tubers used in the country) are deemed to be poor in health, unsuitable in physiological age, poor in genetic quality, impure (varietal mix-up), physically damaged and inappropriate in size. Besides, in the informal seed potato system, seed tubers are produced usually as part of ware and stored under poor conditions (Kassa, 2014). In this seed system farmers usually use varieties of unknown origin and improved varieties are not available to the majority of the farmers. Lack of awareness about the availability and use of improved technology and practices has also impeded adoption of potato technologies. The alternative potato system, which co-exists with the informal seed system in the central and eastern areas, supplies better quality seed tubers than the informal seed potato system (Schulz et al., 2013). However, the amount of seed tubers supplied by the alternative seed potato system is very small $(1.3 \%)$ and thus the system still has limited impact on improvement of potato production in Ethiopia. The formal seed system co-exists with the informal and alternative seed potato systems but only in the central area. It is at the incipient stage and its contribution to the overall seed system is negligible (Hirpa et al., 2015). To narrow the gap between seed supply and demand in most developing countries, 
the seed production system must be accelerated by different rapid seed multiplication techniques. In addition to the quantity of seed supply, improving the quality and productivity of the seed to be produced is pre-request due to disease and quality issues. These necessities could probably be fulfilled if the seed production scheme undertaken in aseptic conditions of controlled environments particularly the multiplication of pre-basic seeds (Ketema et al., 2016; Hirpa et al., 2012).

\section{Challenges of Convectional Seed Potato Production}

Convectional techniques of seed potato production involve the use of potatoes that are propagated by harvesting and replanting the tubers in the field. The tubers used for planting are known as "seed potatoes", as opposed to "potato seeds". Seed potato growers select better quality tubers for seed and discard those of poor quality. The diseased and healthy plants are identified and separated and the healthy tubers are used for next season`s production. However, this method of seed production has proved to be labour intensive, prone to pest and disease infection and time consuming. Considering that vegetatively propagated crops especially potatoes are smooth to both viral and bacterial diseases, the convectional production of seed potatoes favors disease built-up, which drastically reduces crop yield (Badoni and Chauhan, 2010; ElKomyet al., 2010).

The conventional method of propagation is one of the slowest methods of seed multiplication. Compared with other seed propagation techniques like tissue culture and aeroponics, this traditional method would create approximately 8 daughter tubers only in the course of a year (Otazu, 2008; 2010). In addition, the method requires a seed producer to have enough land. This however, is associated with labor cost in managing big fields. The main demerit of this method is that the seed potatoes produced by planting tubers are not 'clean' and found to be of inferior quality. In the absence of continuous sources of good quality seed many growers opt to use their own farm saved seed or those obtained from markets( Ayalew, 2014). Such practices contribute towards sub-optional yields as well as spread of diseases such as bacterial wilt (Ralstonia solanacearum), serious diseases of potatoes, and viruses (Abdurahman et al., 2017; Kaguongo et al., 2008; Gildemacher, 2012; Chindi and Kassa, 2013).

\section{Rapid Seed Potato Multiplication Techniques}

With the collaboration of Ethiopian Institute of Agricultural Research (EIAR), Holetta Agricultural Research Centre and the International Potato Centre (CIP), different rapid multiplication techniques viz. tissue culture produced plantlets, screen house pots, aeroponics, and sand hydroponics have been used to bulk up selected potato varieties for multiplication and distribution 
to growers. CIP has played an important role providing resource poor-farmers in developing countries with a range of new technologies and potato breeding materials specifically designed to suit local conditions . Since September, 2010 selected varieties of Belete, Gudene, Jalene, Awash, have been multiplied using aeroponics (Abebe, et al., 2013). Moreover, the seed production system in the country is being accelerated due to the efficient use of rapid seed multiplication techniques simultaneously at Holetta research centre that supplies quality early generation seeds for major seed producing highlands of the country (Lemma et al., 2017).

\section{Tissue Culture Techniques}

Meristem culture is one of the important plant tissue culture applications for the elimination of viruses from planting materials (Naik and Karihaloo, 2008; Badoni and Chauhan, 2010). It is a procedure in which apical/axillary growing tip $(0.1$ to $0.3 \mathrm{~mm})$ are dissected and allowed to grow in to plantlets on artificial nutrient media under controlled conditions.

This technique for virus elimination is based on the principle that, many viruses are unable to infect the apical/axillary meristems of a growing plant and that a virus free plant can be produced if a small piece meristem is propagated (Kassanis, 2008). Tissue culture is not limited by time of the year or weather (Batool et al., 2014).. In addition, conditions in the laboratory are ideal and therefore, conducive to all year round production scheduling. It also saves an enormous amount of daily care required by convectional cuttings and seedlings (Mahmond, 2006). Tissue culture is also used in somatic hybridization, the induction and selection of mutants and biosynthesis of secondary products. Most developing countries fail to maximize tissue culture technology due to high operational costs involved as it requires specialized equipment which is very expensive to acquire. In addition, different nutrients, energy sources, vitamins and growth regulators used for media formulation are also very expensive (Badoni and Chauhan, 2010).

\section{Aeroponics and Sand Hydroponics Techniques}

As most developing countries, Ethiopia was selected by the international potato centre (CIP) as a pilot country. strengthening innovation capacity of potato-related government organizations would be desirable to start the process as per the project (Ortiz et al., 2013). As the result, scholars began proposing new theories, such as the innovation systems approach, to explain how multiple stakeholders interact, exchange information, generate knowledge and develop innovations for solving problems. And then Aeroponics and sand hydroponics technologies were established in 2010 and 2013, respectively to multiply quality seed potato at Holetta research centre. Since their establishment these technologies strengthen the potato production sector by multiplying thousands of mini-tubers with multiple production per year. 
Soil is just a medium which holds the nutrients required for plant growth, and not a requirement in itself. This fact forms the basics of hydroponics and aeroponics. Hydroponics is basically the process of growing plants using nutrients dissolved in water, without the use of soil. In the case of geoponics, i.e. growing plants in soil, the nutrients in the soil are absorbed by the plants through their roots after they dissolved in water (Factor et al., 2007). In case of hydroponics, these nutrients required by plants are dissolved in water and provided to them directly through their root, and hence soil is not required at all. In general, hydroponics gardens require about $20 \%$ of the overall space required of soil gardens for the same output. Beds for crops grown in water can be made from locally available materials such as discarded tyres or plastic containers and soil-less substrates can be made of rice hulls and round coconut husks (Haythem Mhadhbi, 2012). In aeroponics the plants are hanging in substrates and nutrient solutions are misting to the root systems. In aeroponics the yield and quality of mini-tubers are improved well comparing with other seed production techniques (Lemma et al., 2017, Otazu, 2010).

\section{Seed potato production under screen houses by using pots}

The multiplication of mini-tubers have chains from tissue culture to screen house pots for the purpose of multiplying small sized mini-tubers produced from aeroponics and in-vitro plantlets from tissue culture. Screen house multiplication by pots have an advantage to increase the number of clean minitubers by factor of 7-10 and simultaneously improves the size of the tubers to be planted in open field. As seed potato production in Ethiopia is mainly done by research institutions and collaborating NGOs like CIP, gave emphasis to the potato seed production facilities.

The previously seed production screen houses are now increased from 4 to 14 having the capacity of planting 1800-3500 plantlets of in-vitro or pre-basic tubers depending on the size of pots. Moreover, the source materials for screen houses, production capacities and efficiency as well as quality of mini-tubers produced from these screen houses are transformed due to the establishment and operation of different rapid seed multiplication systems. The capacity of minituber production under screen house pots at HARC was folded since the establishment RMTs of aeroponics in 2010 and sand hydroponics in 2013. The production of early generation seed was increased from 24, 029 in 2008 to 124,591 in 2013 (table 1 ). 
Figure 1: Early generation seed multiplication in screen house pots at HARC (2008-2014)

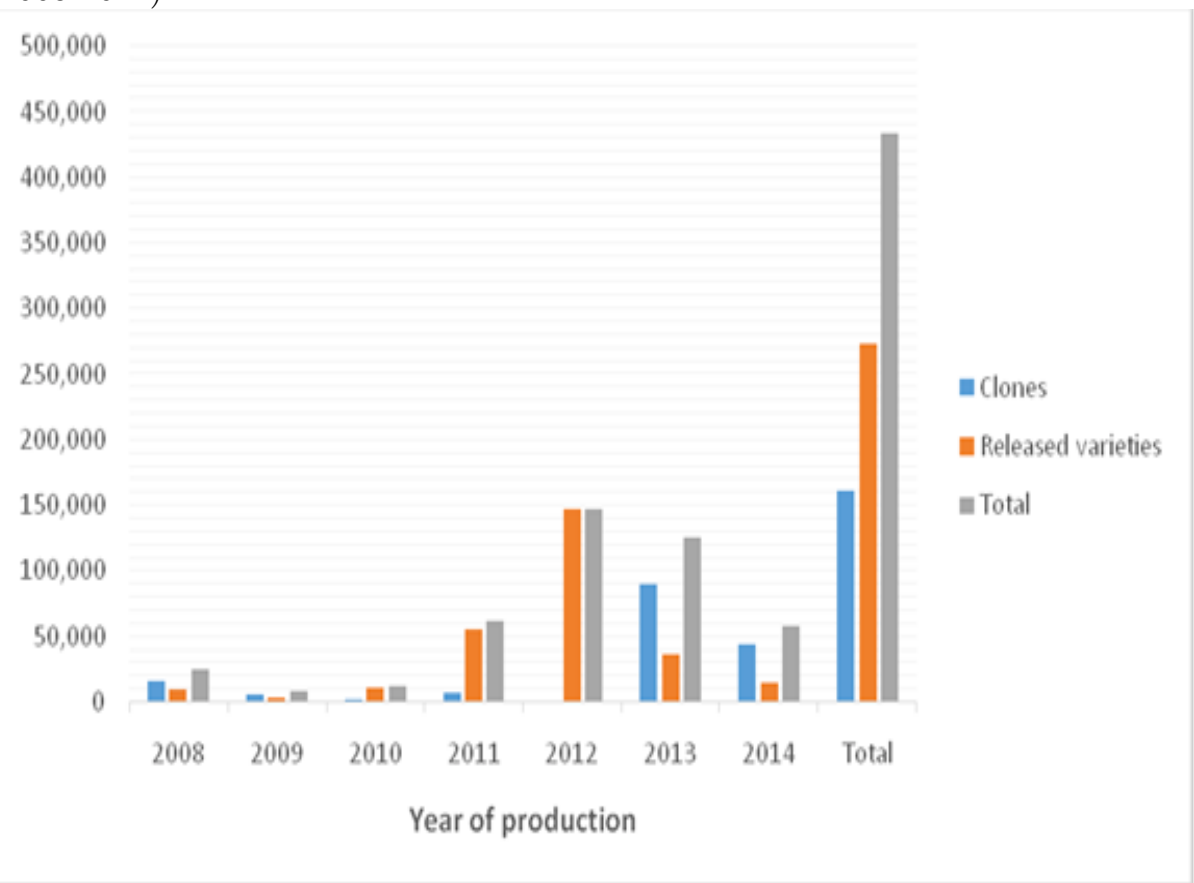

\section{Contributions of rapid seed multiplication systems to the potato sub-sector in Ethiopia}

A low adoption of recommended seed potato (Solanum tuberosum L.) technologies in Ethiopia could be due to a lack of alternative seed potato production methods compatible with farmers' economic and agro-ecological conditions (Hirpa et al,. 2015).There are known crop husbandry technologies and practices that can improve potato productivity (Endale et al., 2008). Seed, a basic component in potato production and which accounts for $40-50 \%$ of its production costs (Wagoire et al., 2005) is in short supply and expensive, especially for smallholder farmers. The national potato programs in Ethiopia depended on low-productivity, sterilized soil substrate-based techniques to generate mini-tubers. Use of stem cuttings planted in open fields and green houses were employed to rapidly increase mini-tubers (MT). Later tissue cultured potato plantlets on sterilized soil substrate were used in screen house to generate generation 1 (G1) clean MT. Both methods were typified with low productivity. To enhance production and utilization of MT, pre-basic and basic seed, the project constructed aeroponics units in Ethiopia in collaboration with USAID funded project.

Massive production of MT using aeroponics significantly reduced the multiplication cycles of seed from nuclear to basic seed from over six to three generations and shortened the time needed to avail basic seed to seed farmers by the national potato research program. This method complemented with conventional rapid multiplication methods such as tissue culture increased the amount of quality seed in the system (CIP, 2012). 
Table 1: Early generation seed produced at HARC by seed potato multiplication techniques.

\begin{tabular}{|c|c|c|c|}
\hline $\begin{array}{l}\text { Seed } \\
\text { multiplication } \\
\text { techniques }\end{array}$ & \multicolumn{2}{|c|}{$\begin{array}{c}\text { Number of mini-tubers } \\
\text { produced }\end{array}$} & $\begin{array}{l}\text { Total mini-tubers } \\
\text { produced } \\
\text { (G1,G2\&G3) }\end{array}$ \\
\hline & $2008-2010$ & $2011-2014$ & $2008-2014$ \\
\hline Aeroponics & - & 206,566 & 206,566 \\
\hline Sand hydroponics & - & 10,161 & 10,161 \\
\hline Screen house pots & 43,773 & 389,969 & 433,742 \\
\hline Grand total & 43,773 & 606,696 & 650,469 \\
\hline
\end{tabular}

Source: Adapted from Abebe et al., 2013.

The Ethiopian potato subsector is vibrant, the potential of this crop to contribute to improved food security and nutrition are increasingly being recognized and future prospects for the seed potato subsector are bright. But, this prospect depends on production and supply of quality seed to the potato farmers, especially disseminating early generation seeds for seed multiplying cooperatives and model farmers trained by research institutions. Currently HARC collaborating with the International Potato Centre (CIP), are applying RMTs of clean seed potato production to accelerate the multiplication capacity of early generation seed. Simultaneously, the production efficiency of minitubers under screen house pots are increasing with the increase of source materials to screen houses from tissue culture plantlets and G1 mini-tubers of aeroponics and sand hydroponics. For example, before starting these seed multiplication techniques, the production capacity of screen house pots in three years (2008 to 2010) was 43,773 mini-tubers. But after supporting our production system with these seed multiplication systems, the capacity of minitubers under screen house was boosted by 7.6\% (332,485 mini-tubers) from 2011 to 2013 production year.

Moreover, these new seed multiplication schemes enhanced the capacity of clean seed production of the country by producing 216,717 mini-tubers of high quality seed from aeroponics and sand hydroponics, which was nil before the establishment of these new technologies. The farmers could also access early generation clean seed potato through their nearby cooperatives with affordable price and with low transportation cost (Chindi et al., 2017). Thus, for developing countries like Ethiopia where formal seed system is infant stages and early generation seed is mostly produced by research centers, the use of various rapid multiplication techniques are very essential to produce clean seed.

\section{Summary and conclusion}

To better harness the potential of potato for food and nutrition security in the face of changing climates, there is need to develop and promote well suited cultivars supported by efficient seed multiplication and delivery systems. Adoption of advanced techniques like micro propagation, micro-tuberization under tissue culture laboratory and hydroponics, aeroponics and pot multiplication under screen houses for production of pre-basic seed. Quality 
planting material is one of the most important ingredients in successful potato cultivation (Muthoni et al., 2013). Shortage of good quality seed is recognized as the most important factor inhibiting potato production throughout the world. The availability of quality planting material of improved potato varieties in adequate quantities, therefore, is the major issue that needs to be attended by respective national agricultural research systems. Once a strong formal seed system is in place it needs to be integrated with informal seed systems, the private seed sector, progressive farmers, seed village clusters, co-operatives and NGOs so that benefits of new varieties and technological advances percolate to the farming communities. Training of the extension officers and farmers through farmer field schools would be an effective medium here.

Potato yields are affected by several factors. Shortage of good quality seed is recognized as the most important factor inhibiting potato production throughout the world. Planting good quality seed is a key component for improving productivity in all agricultural environments and is especially important in developing countries. The current large yield gap between improved seed and farmer-saved seed is due to varietal yield differences, low seed replacement, poor seed quality and low adoption of good agronomic practices. Therefore, the demonstration and incorporation of these recent innovative rapid seed potato multiplication technologies in Ethiopian potato production plan could be very crucial to boost potato yield and bring potato at front as food security and income generating crop of the country.

\section{References}

Abdurahman, A., D. Griffin, J. Elphinstone, P. C. Struik, S. Schulz, E. Schulte-Geldermann and K. Sharma. 2017. Molecular characterization of Ralstonia solanacearum strains from Ethiopia and tracing potential source of bacterial wilt disease outbreak in seed potatoes. Plant patology: 6, 826-834.

Abebe C., W.Gebremedhin, S. Atsede, T. Lemma, N. Kasaye, L.Berga, and S. Schulz (2013). Enhancing potato seed production using Rapid multiplication techniques. In: G. Woldegiorgis, S. Schulz, and B. Berihanu (eds) Seed potato Tuber production and Dissemination. Proceedings of the National Work Shop on Seed potato Tuber production and Dissemination, 12-14 March, 2012. Bahir Dar: Ethiopia.

Ayalew, T., 2014. Analysis of Seed Potato (Solanum tuberosum L.) System with Special Focus nin Ethiopia. Review. Asian J. Agric. Res., 8(3):122-135.

Badoni, A. Chauhan, JS. 2010. Conventional vis-a vis Biotechnological Methods of propagation in potato: A Review. Stem Cell.1:1-6.

Batool, A., Syed S. H. Z., Muhammad, A., Ahsan, M. and Muhammad, N., 2014. Effect of growth regulators in meristem culture of Potato (Solanum Tuberosmum L.). Sci. Tech. and Dev. 33 (2): 80-84.

Berga Lemaga, 2012. The potato value chain in sub-Saharan Africa with case study on Eastern Africa, Kampla, Uganda: sub-Saharan Africa, potato specialist, CIP.

Chindi, A., and Kassa, B., 2013. Seed Tuber Cycle and Latent Infection for the Spread of Potato bacterial Wilt Ralstonia solanacearum (Smith) a Threat for Seed production in Ethiopia. Asian J. plant Pthol., 7(2): 74-83.

Chindi, A., Shunka,E., Solomon, A., W/Giorgis, G., Seid,E., Tessema, L., 2017. Participatory potato seed production: a breakthrough for food security and income generation in the central highlands of Ethiopia. Research Article: 2, 205-212.

CIP, 2012. Wealth creation through integrated development of the potato production and marketing in Kenya, Uganda and Ethiopia. Project Terminal Report.

CIP, 2017. Potato Facts and Figures. [Accessed 23 June 2017] and available at http://cipotato.org/potato/facts. 
CSA (Central Statistical Agency) 2016. Report on Area and production of major crops (private peasant holdings, Meher Season). Agricultural Sample Survey, volume I. Addis Ababa, Ethiopia.

El-komy MH, Abou-Taleb EM, Aboshosha SM, El-Sherif EM, 2010. Different expression of potato pathogenesis-related to proteins upon infection with lateblightpathogene: a case study expression of potato osmotin-like protein. Int. J. Agri. Biol. 12(2):179-186.

Endale Gebre, Gebremedhin Woldegiorgis, and Berga Lemaga, 2008. Potato seed management. In: Root and Tuber Crops: The Untapped Resources. (Eds.) Gebremedhin Woldegiorgis, Endale Gebre and Berga Lemaga. Ethiopian Institute of Agricultural Research (EIAR). ISBN: 97899944-53-19-1. Pg. 53-77.

Factor TL, Araujo JAC de, Kawakami FPC, Lunck V. 2007. Potato basic mini-tuber production in three hydroponic systems. 25(1): 82-87.

Gildemacher, P. 2012. Innovations in seed systems in East Africa. PhD thesis, Wageningen,

The Netherlands.

Gildemacher, P.R., Demo, P., Barker, I., Kaguongo, W., Woldegiorgis, G., Wagoire, W.W., Wakahiu, M., Leeuwis, C., Struik, P.C., 2009. A description of seed potato systems in Kenya, Uganda and Ethiopia. American Journal of Potato Research. 86: 373-382.

Haythem Mhadhbi, 2012. Plant Hydroponic Cultivation: A Support for Biology Research in the Field of Plant-Microbe-Environment Interactions, Hydroponics - A Standard Methodology for Plant Biological Researches, Toshiki Asao (Ed.), ISBN: 978-953-51-0386-8, InTech,

Hirpa, A. T., Miranda P. M. Meuwissen, , Willemien J. M. Lommen, AdmasuTsegaye, Paul C. Struik, Alfons G. J. M. Oude Lansink, 2015. Least-Cost Seed Potato Production in Ethiopia. Potato Research (2015) 58:277-300.DOI 10.1007/s11540-015-9309-1.

Hirpa,A., Miranda P.M. Meuwissen, Ivo A. Van der Lans, Willemien J.M. Lommen, Alfons G.J.M. Oude Lansink, AdmasuTsegaye, and Paul C. Struik. 2012.Farmers' Opinion on Seed Potato Management Attributes in Ethiopia: A Conjoint Analysis. Agron.J: 104(5).

Kaguongo,W., P. Gildemacher, P. Demo, W. Wagoire, P. Kinyae, J. Andrade, G. Forbes, K. Fugilie, Thiele. 2008. Farmer practices and adoption of improved potato varieties in Kenya and Uganda. Working paper 2008-5. International potato center (CIP), Lima, peru.

Kassa, T. Alemu, 2014. Potato value chain in Ethiopia: Cases of Sinan and Bibugn Districts in East Gojjam. Time Journals of Agriculture and Veterinary Sciences, 2(6):114-124.

Kassanis, B., 2008. The use of tissue culture in producing virus-free clones from infected potato varieties. Int. J. Ann. Appl. Biol. 45(3):422-427.

Ketema, M., Kebede, D., Dechassa, N., Hundessa, F., 2016. Determinants of adoption of potato production technology package by smallholder farmers: evidences from Eastern Ethiopia. Review of Agricultural and Applied Economics: 19 (2) 61-68, doi: 10.15414/raae.2016.19.02.61-68

Lemma T., Abebe C., Gebremedhin W., Atsede S., Egata S., Ebrahim S., 2017. Determination of Nutrient Solutions for Potato (Solanum tuberosum L.) Seed Production under Aeroponics Production System. Research Article; 2: 155-159.

Mahamond, O. 2006. Utilization of tissue culture techniques in a seed potato tuber production Schemes. Wageningen. Nethrlands. p.264.

Muthoni Jane, Hussein Shimels and Rob Melis, 2013. Alleviating potato peed tuber shortage in developing countries: Potential of true potato seeds. Review Article. Australian Journal of Crop Sciences, 7(12): 1946-1954.

Naik, P.S., J.L. Karihaloo, 2008. Micro propagation for the production of quality potato seed in Asia-Pacific. Asia-Pacific consortium on Agricultural biotech. New Delhi, India.p.47.

Ortiz O, Orrego R, Pradel W, Gildemacher G, Otiniano R, et al. (2013) Insights into potato innovation systems in Bolivia, Ethiopia, Peru and Uganda. Agricultural Systems 114: 73-83.

Otazu, V. 2008. Manual on quality seed potato production using aeroponics. International Potato Center (CIP). Lima, Peru.

Schulz, S., Gebremedhin W., Gebrehiwot H., Abdulwahab A., J. van de Haar, Shiferaw, W., 2013. Sustainable Seed Potato Production in Ethiopia: from Farm-Saved to Quality Declared Seed. In: Gebremedhin W., S. Schulz and B. Baye (Eds). Proceedings of the National Workshop on Seed potato tuber production and disseminations: experiences, challenges and prospects. Pp.60-80. Ethiopian Institute of Agricultural Research and Amhara Region Agriculture Research Institute, 12-14 Mach 2012, Bahir Dar, Ethiopia.

Wagoire W.W., R. Kakuhenzire, I.N. Kashaija, B. Lemaga, P. Demo, and G. Kimoone. 2005. Seed potato production in Uganda: Current status and future prospects. African Crop Science Society Conference Proceedings 